\title{
RELATIONS BETWEEN RIVER CHEMISTRY AND ITS PHYTOPLANKTON. CASE STUDY - TIMIȘ RIVER (BANAT, ROMANIA)
}

Hanelore MUNTEAN *

* Banat River Basin Administration - Timişoara National Administration Apele Române, Mihai Viteazul Boulevard 32, Timişoara, Timişoara Country Romania, RO-300023, hane_elena@yahoo.com

DOI: 10.2478/trser-2013-0032

KEYWORDS: phytoplankton, water chemistry, correlation, integrated approach, Timiş River.

\section{ABSTRACT}

The river plankton - potamoplankton - consists predominantly of autochthonous as well as allochthonous elements and it is poorly represented in rivers due to the water flow. The allochthonous elements that reach streams from stagnant waters suffer changes or, if they cannot adapt to the environment, quickly die. Usually, in a current stronger than $1 \mathrm{~m} / \mathrm{s}$ they do not survive. Potamoplankton variety increases from spring to effusion, plankton being almost completely absent in the region of the spring.

In medium and small basins, places with stagnant water are formed and plankton growth is supported, but in areas where there are no crossings and water speed is too high, plankton is destroyed due to mechanical action.

In rivers, phytoplankton mainly consists of diatoms, chlorophytes, euglenophytes and cyanobacteria, etc.

The aquatic environment is wide, having various physico-chemical characteristics which determine different ecological conditions, so that the distribution of aquatic animals and plants differs.

Aquatic ecosystems are structural and functional units consisting of biotopes and biocenosis that support self-integrated activities, the result being biological production and destruction.

Timiş River was monitored in 2012 in the months of May and September in the Lugoj, Hitiaș, Şag and Grăniceri sections. Also $\mathrm{pH}$ was monitored for oxygen and the nutrient flow of these sectors and interpretations and correlations of the phytoplankton quality indicators were made.

RÉSUMÉ: Les relations entre la chimie de la rivière et son phytoplancton. Etude de cas - la rivière Timiș (Banat, Roumanie).

Le potamoplancton, plancton des rivières, est formé d'éléments autochtones prédominants, ainsi que d'éléments allochtones. Il est faiblement représenté dans les rivières à cause de l'écoulement d'eau. Les éléments allochtones, arrivés dans les rivières à partir des eaux stagnantes, subissent des modifications ou meurent rapidement car ils ne s'adaptent pas aux nouvelles conditions environnementales. En règle général, au delà d'une vitesse de $1 \mathrm{~m} / \mathrm{s}$, le potamoplancton ne survit pas. Le nombre d'espèces de potamoplancton augmente de la source vers le débouché; le plancton étant quasiment inexistant au niveau de la source. 
Dans les bassins moyens et inférieures, des eaux stagnantes apparaissent et permettent le développement du plancton. Au niveau des zones où la vitesse de l'eau est trop grande, le plancton est détruit par action mécanique.

Dans les rivières, le phytoplancton est formé principalement de diatomées, suivis de chlorophycées, d'euglenophytes, de cyanobactéries etc.

Le milieu aquatique est particulièrement riche, avec des caractéristiques physicochimiques variées déterminant des conditions écologiques tout aussi variées, menant ainsi à une répartition différenciée des organismes aquatiques d'origine animale et végétale.

Les écosystèmes aquatiques représentent des unités structurelles et fonctionnelles formées du biotope et de la biocénose ayant une activité intégrée, le résultat étant la production et la dégradation biologique.

La rivière Timiș a été suivit en 2012 durant les mois de mai et septembre dans les sections de Lugoj, Hitiaş, Şag et Grăniceri. Le pH, le flux d'oxygène et de nutriments y ont été relevés puis interprétés et corrélés avec les données du phytoplancton en tant qu'indicateur de qualité. râul Timiş.

REZUMAT: Legături între chimia râului şi fitoplanctonul acestuia. Studiu de caz -

Planctonul din râuri, numit şi potamoplancton, este format atât din elemente autohtone, cât şi alohtone şi este slab reprezentat datorită curgerii apei. Elementele alohtone, ajunse în apele curgătoare din apele stătătoare, suferă modificări sau, dacă nu se pot adapta la noile condiţii, mor repede. De obicei, la o viteză de curgere mai mare de $1 \mathrm{~m} / \mathrm{s}$ fitoplanctonul nu supravieţuieşte. Varietatea potamoplanctonului creşte de la izvoare spre vărsare, la izvoare planctonul fiind aproape inexistent.

În bazinele mijlocii şi inferioare se formează locuri cu apă stătătoare, unde dezvoltarea planctonului este avantajată, însă, în zonele unde există praguri şi viteza apei este prea mare, planctonul se distruge prin acţiune mecanică.

În râuri, fitoplanctonul este format în principal de diatomee şi în număr mult mai mic din cloroficee, euglenofite, cianobaterii etc.

Mediul acvatic este deosebit de vast, cu variate caracteristici fizico-chimice ce determină diferite condiţii ecologice, astfel repartizarea organismelor acvatice, fie vegetale fie animale, este diferenţiată.

Ecosistemele acvatice reprezintă unităţi structurale şi funcţionale, alcătuite din biotop şi biocenoză, care desfăşoară o activitate integrată, rezultatul fiind producţia-distrugerea biologică.

Râul Timiş a fost monitorizat în anul 2012, în lunile mai şi septembrie în secţiunile Lugoj, Hitiaş, Şag şi Grăniceri. S-a monitorizat pH-ul şi regimul oxigenului şi cel al nutrienţilor în aceste secţiuni şi s-au realizat intepretări şi corelaţii cu indicatorul de calitate fitoplancton.

\section{INTRODUCTION}

In 1991, in order to avoid the long term qualitative and quantitative water degradation, the problem of implementing a new program related to the sustainable use of water resources up to year 2000 came about.

On November 10th, 1995, the "Environment in the European Union" report elaborated by the European Environmental Agency, the up-to-date situation of water resources. The conclusion came to be the necessity to take action towards the qualitative and quantitative water protection in the community. 
For maintaining and improving the aquatic environment, qualitative and quantitative control of waters, the directive has to develop principles and structures for the sustainable use of water resources over a long period of time.

The directive has to contribute to a decrease in pollutant emission in waters towards a better control of the cross-border water problems and aquatic ecosystem protection.

An integrated approach including not only qualitative and quantitative elements, but the hydrological floating conditions of waters contribute to a better environment protection.

This paper describes the study of Timiş River from upstream from Lugoj city until upstream of Grăniceri. Timiş River, first degree tributary of the Danube, springs from the eastern part of the Semenic Mountains, below Piatra Goznei Peak (1145 m), from $1280 \mathrm{~m}$ height, having a lenght of $244 \mathrm{~km}$ (in Romania), gathers the waters of 150 rivers, measuring a lenght of the hydrological system of $2434 \mathrm{~km}$ and a density of $0.33 \mathrm{~km} / \mathrm{km}^{2}$. The river basin area is of $7310 \mathrm{~km}^{2}$. In its mountain sector, Timiş receives two small tributaries: Brebu and Semenic, and after $25 \mathrm{~km}$ from its spring it enters Timiş-Cerna couloir where it receives tributaries both from Semenic and Tarcu Mountains (the tributaries from the right side are bigger): Teregova, Râul Rece (Hidegul), Feneş, Sadoviţa, Goleț, Bolvaşniţa. At Caransebeş it confluences with Sebeş River, after which Timiş River receives its greatest tributary, Bistra.

Afterwards, Timiş's alluvial cone starts under the shape of a fan until the border with Serbia. In the arial of this cone, a gradual deviation of Timiş River to the right can be noticed, especially due to its tributaries a little bit bigger to the left. Timiş river's deviation to the right is highlighted by its abandoned course, Timişul Mort, which used to be the main course. The route followed by Timiș River, has a tortuosity coefficient of 2.50 and an average slope of 5\%, a flinty geology with a river bed made of boulders, gravel, sand and silt (Nagy et al., 2004).

\section{MATERIALS AND METHODS}

Chemical samples were collected from four sectors of Timiş River twice in the year 2012. Samples were collected according to the standards in force under the WFD for each chemical indicator of water quality.

From a biological point of view, phytoplankton samples were collected, according to Draft N 109/2008/04/15 Draft proposal for "Water Quality-Guidance on quantitative and qualitative sampling of phytoplanktonfrom inland water" and processed according to SR EN 15204 - Ghid pentru analiza de rutină a abundenței şi compoziției fitoplanctonului prin utilizarea microscopiei inverse (metoda Uthermol), determining the taxonomical cathegories present; density and biomass.

\section{RESULTS AND DISCUSSIONS}

It is known that the physico-chemical characteristics of water plays an important role in understanding the processes that take place in the aquatic environment and that influence the development and functionality of aquatic biocenosis.

More chemical parameters are taken into consideration in order to establish water quality classes. A very important parameter is $\mathrm{pH}$, which has a very important role in the processes that take place in the aquatic environment. $\mathrm{pH}$ varies by day and night, during the night due to organism breeding and the release of $\mathrm{CO}_{2}$ into water, and in the day-time its value increases due to photosyntesis. In surface running waters, $\mathrm{pH}$ value is between $3.4-6.95$ for acid environments, $6.95-7.3$ for neutral environments and $>7.3$ for the basic ones. Aquatic organisms prefer the neutral $\mathrm{pH}$ to a little bit alkaline (Varaduca, 1997).

Along Timiş River, in the studied sectors, $\mathrm{pH}$ has the following values (Fig. 1). 


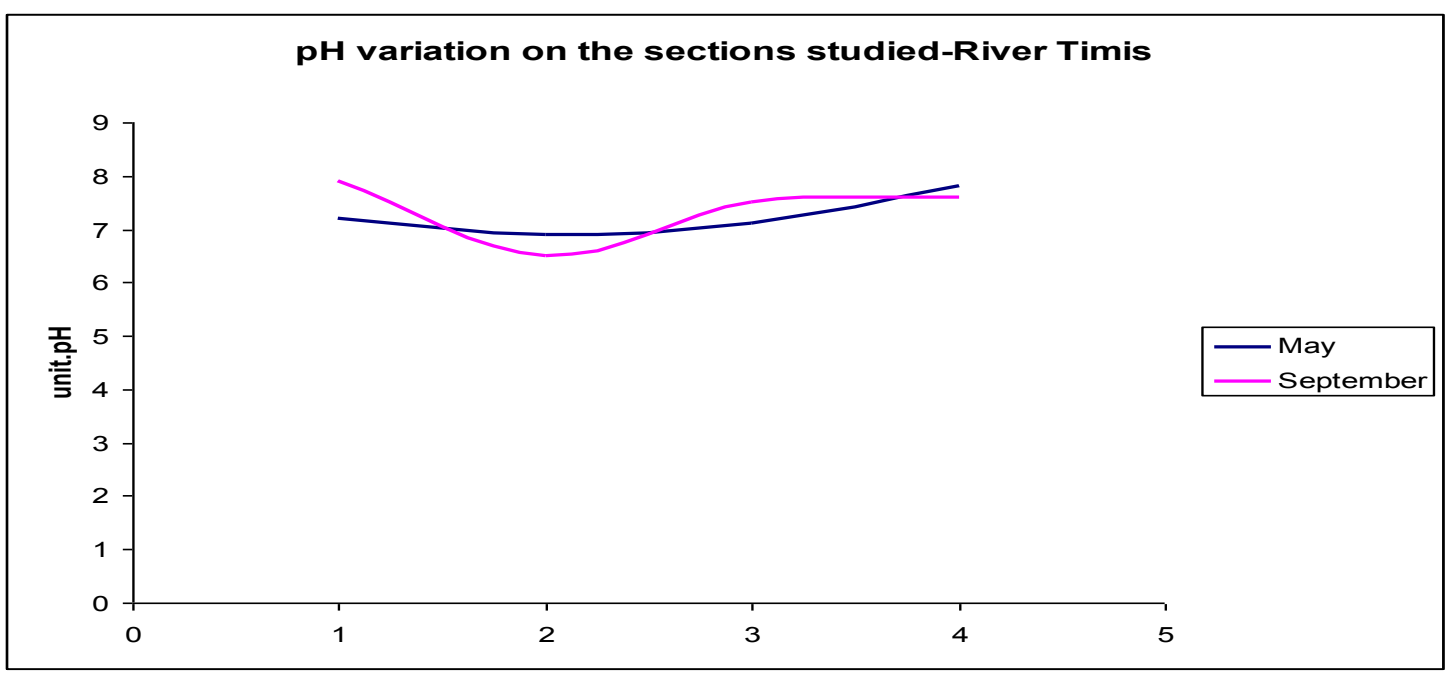

Figure 1: pH fluctuations in the monitored sectors, respectively monitored months.

\section{Variation of dissolved oxygen in sections studied-River Timis}

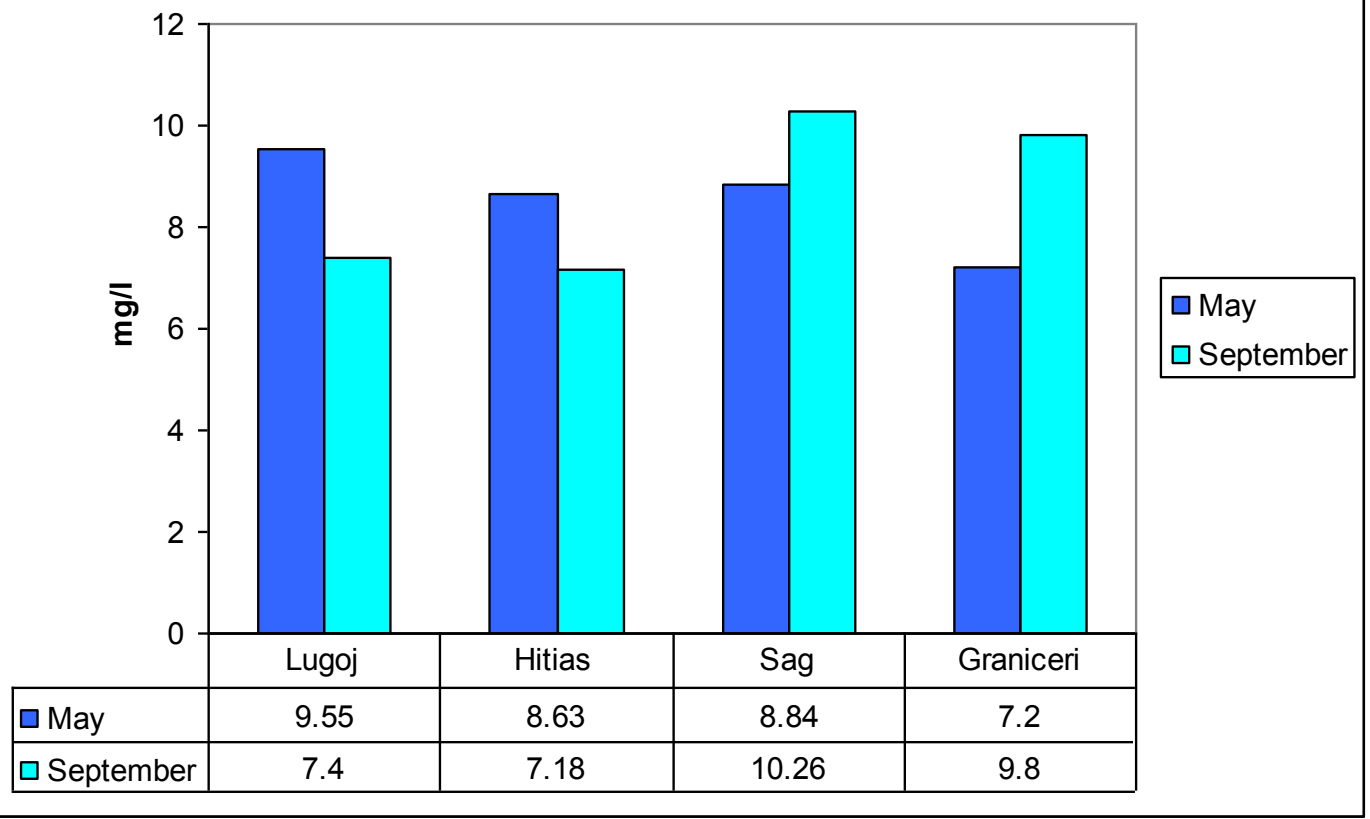

Figure 2: The fluctuation of dissolved oxygen in the monitored sectors.

The $\mathrm{pH}$ varies among sections and from one monitored period to another, the smallest $\mathrm{pH}$ being in September in Hitias, with a value of 6.4, which is similar to the water in an acid environment, and the highest value is in Lugoj sector $(\mathrm{pH}=7.9)$, the environment being basic.

Oxygen regime contains the concentration of saturated oxygen and the group of substances that biodegrade through biochemical reactions that consume oxygen.

Dissolved oxygen is the most important parameter for aquatic ecosystems, which is the existence and survival of aquatic organisms being limited by its quantity. 
The quantity of dissolved oxygen also shows the oxidation level of the residues and its effects upon water ecosystems, the self-cleaning capacity of these ecosystems. Disolved oxygen from waters comes from the gas exchange between water and atmosphere (exogenous) and photosynthesis of aquatic organisms (endogenous) (Varaduca, 1997).

The quantity of dissolved oxygen consumed by aquatic organisms or in different processes is replaced by another quantity from the atmosphere or from photosynthesis (Mălăcea, 1969).

Timiș River is characterized by a relatively good oxigenation (Fig. 2).

Independently of the season or the monitored sector, the quantity of dissolved oxygen is high, which shows that this river sector has a high self-purification capacity and a good biological productivity.

Biogenic substances contain chemical elements with a restrictive character that contribute to the development of the aquatic organisms.

Nitrite, nitrate and ammonia are formed in waters as a consequence of the decomposition and mineralization of the protein products that enter surface water together with waste waters. Indirectly, different forms of nitrogen can reach surface and underground waters due to diffuse pollution from agriculture and stock raising.

A high quantity of ammonia together with a high quantity of nutrients in the water indicate pollution from a certain past time, while ammonia without nitrites being present indicate a recent pollution.

Waters that cross fields rich with humus contain high quantities of phosphates, which can also come from diffuse pollution (Varaduca, 1997).

In the studied area, these parameters characterize water quality (Fig. 3). The monitored sections are characterized during all seasons by an almost equal phytoplankton density. Only in September in Grăniceri sector the density drops to half compared to the month of May.

The predominant species in Lugoj sector in the month of May are: Cocconeis pediculus, Cymbella cistula, Cymbella ventricosa, Diatoma vulgaris, Diatoma ehrenbergii, Nitzschia acicularis, and in September: Cocconeis pediculus, Cymbella tumida, Navicula capitatoradiata, Diatoma vulgaris, Cyclotella meneghiniana, Dydimosphenia geminata species (Fig. 5) has been identified for the first time in Prut River, then in Bistrița River and in Bicaz dam basin. Recent data shows that Didymosphenia geminata appeares suddenly in the year 2000 and can be abundently found in a few rivers from Transylvania, like: Someşul Rece, Someşul Cald, Someşul Mic, Crişul Repede, Valea Drăganului, Arieş River, Mureş River and Olt River. Today situation in Romania, characterized by the lack of monitoring programs for the algae in many aquatic ecosystems make the evaluation of the impact caused by this species to the already existing communities impossible (Momeu, 2009).

The results of many authors of Europe, Asia, New Zeeland, North America concerning the invasive behaviour of $D$. geminata shows that the massive development of this species affects the habitat of benthic macroinvertebrate and fish species. A decrease is also shown in number and abundance of some invertebrate groups like Chironomidae and Oligochaeta that feed on algae, but can not consume Didimosphenia geminata. The high development of this species leads to "water blooming" and affects the dissolved oxygen not only during the vegetation period, but also in the decomposition of the organic matter period, due to mucilaginous peduncles. Didymosphenia geminata causes problems to humans aswell, like eye irritations (Momeu, 2009). 


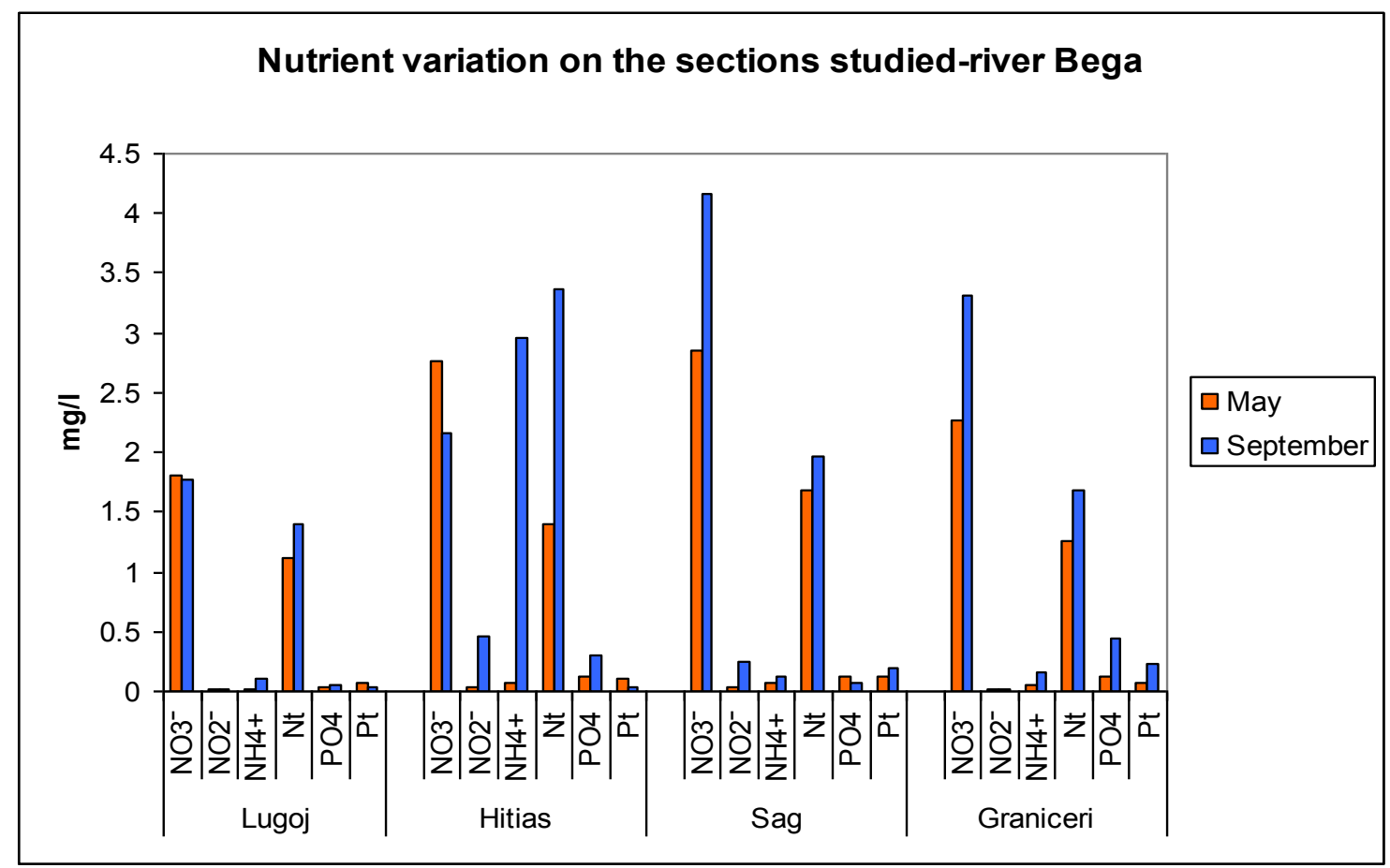

Figure 3: Nutrient variation in the studied sections.

In the given chemical conditions, phytoplankton varies in the studied sections as it follows in figure number 4.

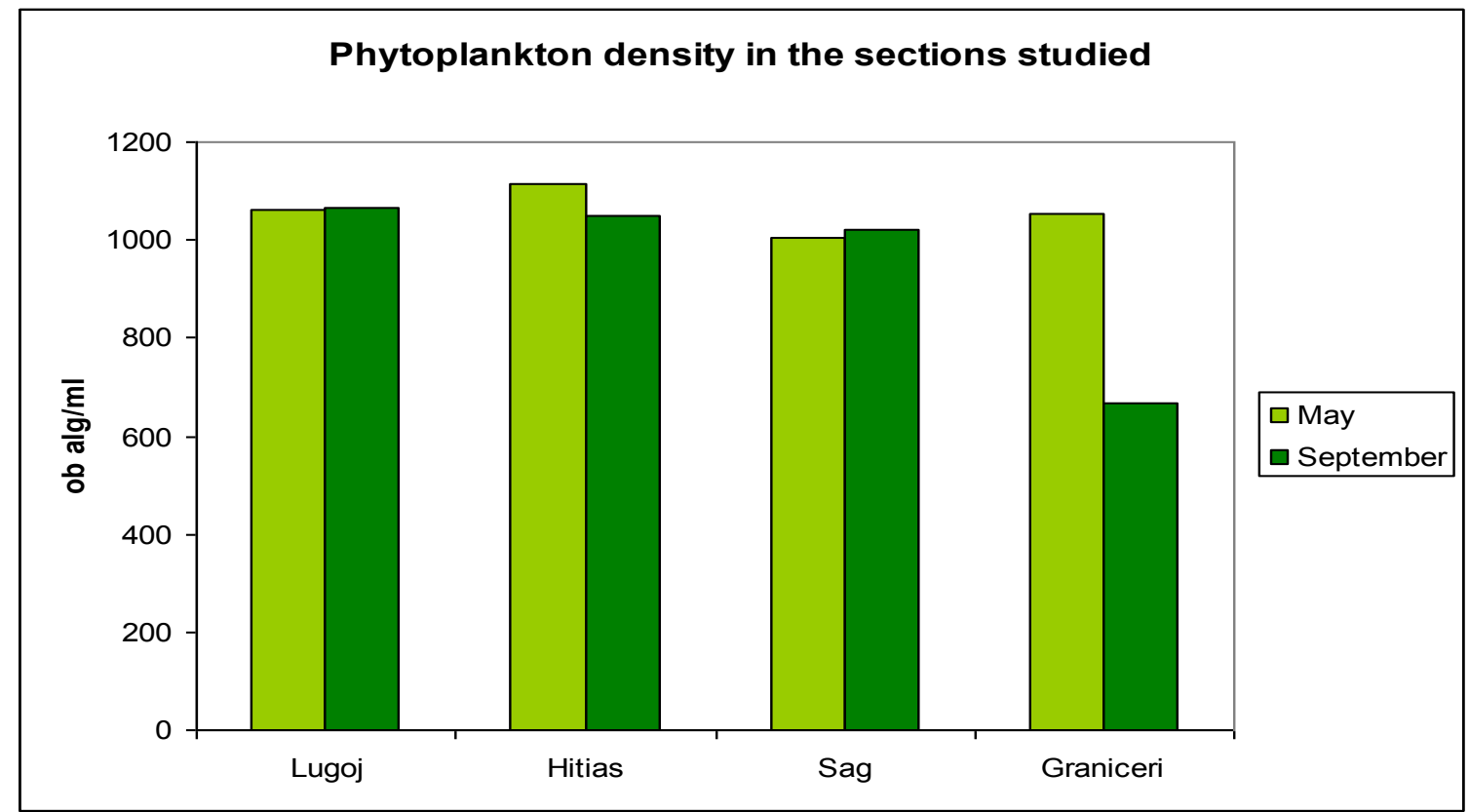

Figure 4: Phytoplancton density in studied sections.

Didymosphenia geminata has been identified in Timiș as well, in Lugoj, Hitiaş, Şag and Grăniceri areas. From Lugoj, it stopped migrating towards the upper Timiș River sector. 


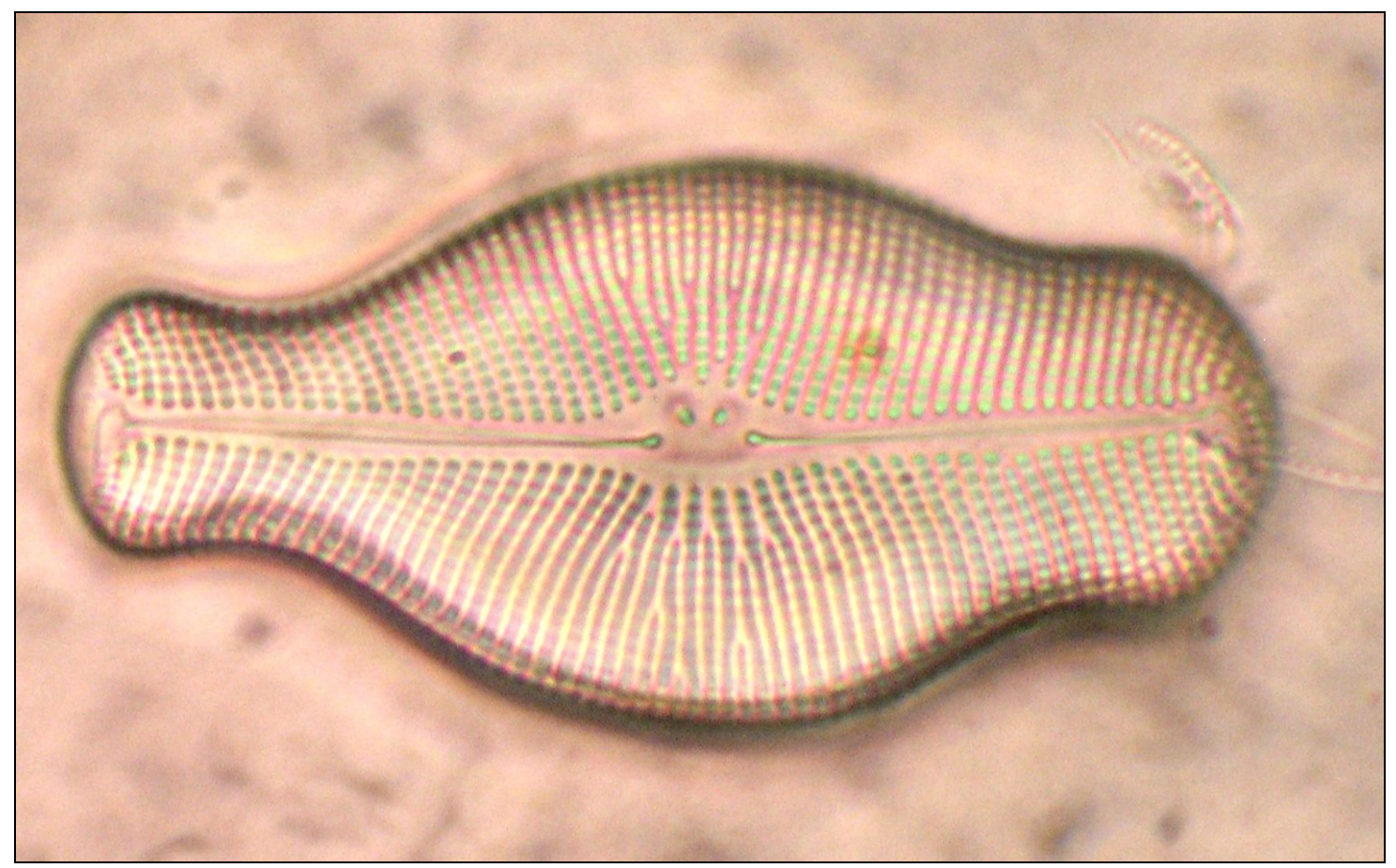

Figure 5: Didimosphenia geminata.

In Hitiaș sector, the dominant species are: Cocconeis pediculus, Diatoma mesodon, Diatoma vulgaris, Fragilaria crotonensis, Synedra acus, Ulnaria ulna, in May and September predominate: Caloneis silicula, Cymbella cuspidata, Diatoma vulgaris, Navicula bacillum.

In Şag section, in the month of May predominate: Ccocconeis placentula, Cyclotella meneghiniana, Diatoma vulgaris and Nitzschia levidensis, and in September: Cocconeis pediculus, Cymbella tumida, Fragilaria crotonensis, Ulnaria ulna.

Grăniceri sector is characterized in the month of May by the following species: Asterionella formosa, Fragilaria crotonensis, Melosira varians, Navicula cryptocephala, and in September the dominant ones are: Cocconeis pediculus, Diatoma vulgaris, Navicula capitata, Stephanodiscus hantzschii and Ulnaria ulna.

The algae species vary from one season to another and from one species to another. The phytoplankton biomass varies too, as follows (Fig. 6):

In September, in Şag section we have the biggest phytoplancton biomass and the highest quantities of nitrate, nitrite and total phosphorus, which reveals the nutrients influence onto the aquatic flora growth.

The highest quantity of ammonia was found in September in Hitiaș sector, but neither the density, biomass, or the number of phytoplanktonic algae were influenced by it. The highest quantity of total nitrogen/azote was found in Hitiaș section in September, but it doesn't influence the density nor the phytoplankton biomass.

Didimosphenia geminata was not present in Şag section in May, in Hitiaș and Grăniceri sections in September. In these months, the phosphates have high quantities, which reveals the fact that this species does not grow when high quantities of phosphate are present, especially because in the Lugoj section this species was found in both monitored months, where the phosphate quantity is the lowest out of all the studied sections. 


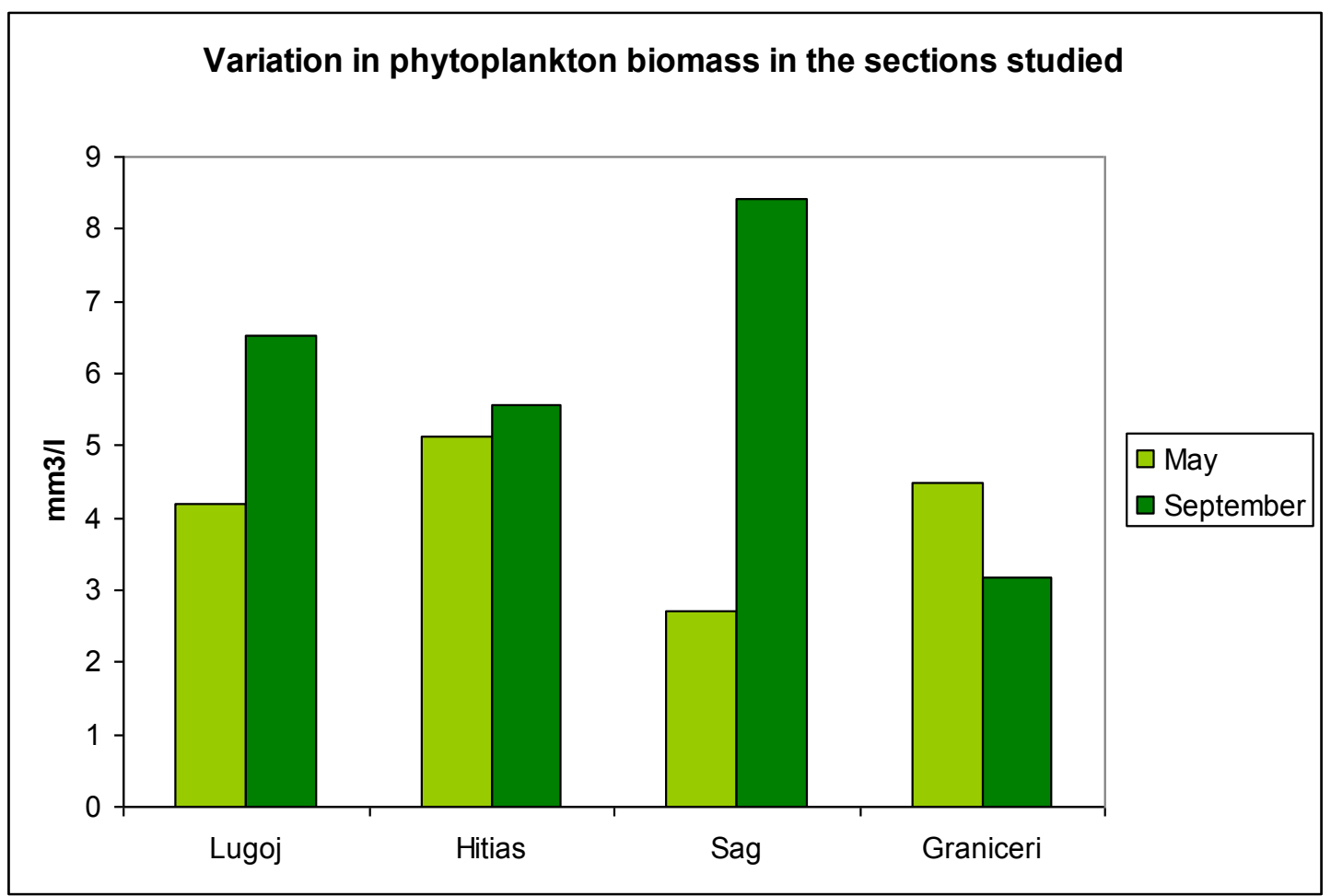

Figure 6: Phytoplanktonic biomass fluctuation in the studied sections.

The main phytoplankton species vary from one river section to the other and from one season to another.

Nutrients influence phytoplankton biomass growth.

Ammonia does not inhibit nor influence the phytoplankton evolution.

Didimosphenia geminata doesn't grow in waters with high content of phosphates.

\section{REFERENCES}

1. Mălăcea I., 1969 - Biologia apelor impurificate, Editura Academiei Române, Bucureşti, 130131. (in Romanian)

2. Momeu L., 2009 - Problems concerning the invasive species from continental aquatic ecosystems Case study: Didymosphenia geminata (Lyngb.) M. Schmidt in Rakosy L. and Momeu L. (eds.), Neobiota din România, Presa Universitară Clujeană, 11-30.

3. Nagy C. and Şerban P., 2004 - Raportul 2004, Planul de Management al Spaţiului Hidrografic Banat, Administraţia Bazinală de Apă Banat, Timişoara, 4-55. (in Romanian)

4. Varaduca A., 1997 - Hidrochimie şi poluarea chimică a apelor, Edit. *H*G*A*, Bucureşti, 3465. (in Romanian)

5. $* * * * *$ Legea 107/1996, 1996 - Monitorul Oficial, Bucureşti. 